\title{
The recruitment and selection of pension trustees: an integrative approach
}

\author{
Susan Sayce, Norwich Business School, University of East Anglia \\ Johanna Weststar, Dan Program in Management and Organizational Studies, \\ Western University \\ Anil Verma, Rotman School of Management \& Centre for Industrial Relations and \\ Human Resources, University of Toronto \\ Human Resource Management Journal, Vol ••, no ••, 2012, pages ••-••
}

\begin{abstract}
The role of a pension trustee is significant, which makes the recruitment and selection of labour trustees an important issue. In this article, we examine and combine aspects of two approaches to recruitment and selection: the political nomination model and the more professional HRM approach. We argue that an integrative approach would acknowledge the political, regulatory and organisational context while incorporating valid selection criteria such as domain-specific skills and performance on the job. Such an integrated process can help trade unions in filling labour trustee positions with talented individuals who are more likely to be effective in achieving labour's goals in pension governance.

Contact: Dr Susan Sayce, Norwich Business School, University of East Anglia, Norwich NR4 7TJ, UK. Email: s.sayce@uea.ac.uk
\end{abstract}

\section{INTRODUCTION}

A discernible worldwide trend towards giving pension plan members greater say in pension governance has emerged in the last half-century. In the context of unionised workplaces, this has led to more union trustees on pension boards. The increasing presence of employee representatives on pension boards has attracted some scrutiny of their role and effectiveness. Although research on this topic is still lacking, it has been found that labour (or employee) representatives on pension boards may not be fully participative members of the board (Weststar and Verma, 2007; Verma and Weststar, 2011).

The role of trustees on a pension board is challenging at the best of times; shifting demographics, turbulent markets, heightened economic pressures and movements in support of alternative investment strategies further complicate the landscape. Labour trustees are not often experts in pension governance, investment policy or actuarial science, and they must acquire a degree of functional competence to operate on the board. Moreover, they experience a heightened political environment because of their actual or perceived union allegiance. Labour trustees must negotiate the tension between their fiduciary duty to the plan and their duty of representing the values in their own trade union. Therefore, trustees experience a degree of both role conflict and role ambiguity (Rizzo et al., 1970).

All of the above make the recruitment and selection of the right candidate fraught with problems. This article examines two alternate approaches to the recruitment and selection of labour trustees: the nomination approach, which is more political in nature, and the more professional HRM approach. The nomination approach emphasises the overall political goals of the organisation (here, the union) and the nominated individuals' political connections to the union leadership. In contrast, the HRM approach emphasises development of a job description backed up by formal job analysis, advertising the job description widely to generate a pool of 
qualified applicants and a selection process consisting of validated tests and interviews. To HRM professionals, any process that circumvents these essential steps would result in placement errors. We compare and contrast the two alternate approaches to identify the strengths and weaknesses of each as it applies to placement of labour trustees. We argue that unions would benefit from incorporating key elements of the HRM approach into their own nomination approach. Rather than establish a new dichotomy from which to advocate a particular set of trustee characteristics that are necessary for fund governance and performance (the prudence versus professionalism debate), we attempt to synthesise these poles. We suggest that a blended approach to recruitment and selection could result in labour trustees with more skills in both the political and the professional realms. This would result in greater functional competence, less role ambiguity and more effective participation on the pension board in pursuing labour's goals.

\section{LABOUR TRUSTEES ON PENSION BOARDS}

In Anglo-Saxon contexts, including Canada, Australia, the US and the UK, the composition of pension fund boards has become more diverse in terms of affiliation, skills and experiences, including cultural and socio-demographic aspects (Clark, 2007; Rafferty et al., 2008; Sayce, 2012; Sayce and Ozbilgin, 2013). With the support of trade unions, diversity has increased through greater numbers of plan members and retirees as pension trustees (Gribben and Olsen, 2002; Hess, 2005; Sayce and Gold, 2011). Such diversity is often viewed as an important regulatory mechanism within the corporate governance literature (Tyson, 2003). Diversity and representation can enhance board effectiveness as it reduces agency costs through monitoring the management's inherent conflicts of interests with stakeholders (Daily et al., 2003). Carter et al. (2003: 36) also report a positive relationship between board diversity and firm value among Fortune 100 firms in the US.

In the Anglo-Saxon model, pension trusteeship is an executive decision-making role with a high level of legal and moral responsibility (Kakabadse et al., 2003). Trustees oversee significantly large financial assets. ${ }^{1}$ Their negotiations with corporate sponsors over the funding of occupational pension plans affect the pension outcomes of plan members. Moreover, as institutional shareholders, pension funds exert a dominant role in global financial markets and are influential in shaping global corporate investment policy.

Given the importance of the trustee role and the diversification of trustees through increased member representation, a debate has arisen regarding the benefits and risks of so-called 'lay' trustees and the skills and education that are required for trustees to effectively fulfil their fiduciary role. Clark et al. (2006) and Ambachtsheer et al. (2008) consider that well-intentioned amateurs can complicate and limit the decision making of pension plans. Clark (2007) claims that the tension between expertise and representation is increasing as institutions search for appointees capable of performing well during periods of turbulent financial markets and underfunded liability crises such as those experienced by Canada, the US and the UK over the past decade. Although investment experts also face this uncertainty, Woods and Urwin (2010: 8) claim that they are better able to test and modify their thinking than other naïve investors.

Clark (2007: 9) argues that representatives need advanced quantitative skills, probabilistic reasoning and numeracy skills to adequately monitor the actions of delegated agents; otherwise, they can become too reliant on legal, financial and investment experts' advice. Evidence cited to support these claims is a pension trustee experiment that contrasted Oxford 
graduates with a self-selected group of pension trustees (Clark et al., 2006). It was found that when it came to strategic investment decision making, the graduates were more consistent than the pension trustees.

Myners (2001) too was concerned about expertise versus representation. He suggested that the standard of prudence, common law praxis, be raised from 'rational decisions by an ordinary man' to one where decisions are made with 'the skill and care of someone familiar with the issues concerned'. He acknowledged that it would be unrealistic for all trustees to undergo extensive training to gain deep expertise, but he recommended that trustees should collectively improve board expertise. Myners (2001: 21) stated that trustees should 'assess the effectiveness of their own contribution to meeting the objectives of the fund', and consider:

- whether the decision-making structures they have in place address the task of effectively running their fund;

- whether the division of time between their various responsibilities is right;

- whether they have the right mix of skills and experience collectively; and

- whether the fund's control environment is fit for the purpose.

This recommendation illustrates that pension boards are responsible for setting their own standards and uniquely defining trustee roles and responsibilities vis-à-vis their oversight role. Like Myners, Ambachtsheer et al. (2008) also support greater professionalism in trusteeship but emphasise the importance of the board's internal capacity to set and maintain standards to achieve strong oversight. Reviews of corporate board dynamics (Huse, 2005; Van der Walt et al., 2006) reveal the interrelationships of decision making where coalitions between others can influence the decision-making process and board outcomes. Thus, if trustees become too entangled in financial and investment detail, there is a danger that they descend into micromanagement, losing oversight of the broader dynamics of the decision-making process needed for good pension governance (Ambachtsheer, 2007: 5).

Ambachtsheer's more functional approach to pension governance recommended clarity about the organisation's purpose through an examination of the boards' role and accountability to stakeholders, and to set out management's role in meeting board expectations. Yet, perhaps more fundamental to this and all principal-agent scenarios is the motivation that trustees are able and willing to use their 'wisdom, skills and experience' to deliver the organisation's pension objectives (Ambachtsheer, 2007: 5). Central to this motivation is the sense that the pension trustee is a caretaker of the fund. Boxall and Purcell (2011: 26) indicate that motivation is a 'fragile' concept because it is linked to unpredictable interaction between different parties, and in governance, this includes negotiating the different perspectives of stakeholders' representatives.

However, for Ambachtsheer et al. (2008), representation is not enough. Expertise is also needed to counter perceived weaknesses in trustees' oversight to combat potential moral hazard and conflict of interest. Labour trustees are often asked to 'leave their union hat at the door', but in some cases, labour representatives could face the risk that the strengths of common law praxis, such as integrity, honesty, accountability and independence, would be subsumed under the imperatives of professional management praxis. This could undermine their participation, particularly in private pension plans, where, according to a member of Quebec's Expert Pension Committee, the board may include 'management conscripts' because of their conciliatory relationship to the employer rather than for their knowledge or competence. Based on our research, this practice poses a particular hazard given the tendency for trustees to delegate decision-making power. This delegation occurs to external advisers such 
as fund managers, actuaries and pension staff, and to pension board subcommittees where there is a tendency to self-select based on perceived or assumed skills. Such a division of labour undermines the oversight capacity of the board and has high agency costs.

Leblanc (2004) argued that to understand the black box of corporate governance, one has to focus on board processes and board members' behaviour as well as their skills. As Pye and Pettigrew (2005: 31) outline, a specific behavioural act 'gains meaning in situations that are located in time'. In this case, the behavioural processes behind a board's attempts to reach consensus are rooted in the structure, culture and political power dynamics of the particular pension plan arrangement as well as the regional, industrial, economic, social and political contexts in which the organisation and the plan operate. Kakabadse and Kakabadse (2005: 582) acknowledge that there may be an advantage to financial expertise, but they conclude that 'being well qualified and financially well versed are not perceived determinants of effective performance for pension fund trustees'. Rather, they emphasise the importance of wider life and work experiences: open-mindedness, willingness to learn, ability to listen and work with colleagues, and knowing how and when to access internal and independent expertise.

In the face of this debate, Kakabadse and Kakabadse (2005: 570) claimed that the focus should not be on polarity between prudence and professionalism or expertise and representation, but on how HRM involvement could help enhance trustee performance and effectiveness through recruitment and selection. Tyson's (2003: 9) recommendations for the selection and development of non-executive directors advocate that standard HRM practices should be used to elicit a broader applicant pool while simultaneously meeting the dual criteria of representation (diversity) and competence.

Our article addresses this call by exploring the implications of an HRM-based recruitment and selection approach and the political nomination method for union pension trustees. It argues that an integrated approach would result in a process that sidesteps the professionalism and prudence debate by creating a system that attracts a broader pool of candidates, where the values of both prudence and professionalism can coexist in a chosen candidate rather than favouring one over the other.

\section{METHODOLOGY}

To reveal the political as well as practical experiences of nomination, appointment and election to the labour trustee role, we revisit three sources of previously collected data (Weststar and Verma, 2007, 2008; Sayce and Gold, 2011; Verma and Weststar, 2011). Data sources include semi-structured interviews with 14 policy makers and experienced pension trustees including six labour trustees in two Canadian provinces (2008); 20 semi-structured interviews with Canadian labour trustees (2004); and a survey of 116 Canadian labour trustees (2005). We examine this data with a mixed method approach (Tashakkori and Teddlie, 2010) that allows us to assess complementary (Greene et al., 1989) experiences with both the political and the HRM approaches to recruitment and selection.

It is important here to note the applicability of research in the Canadian context to other Anglo-Saxon countries. The Canadian trend towards greater union involvement in pension trusteeship mirror those in countries such as the US, UK and Australia, although the specific legislative context that allows for member representation may vary somewhat across jurisdictions. In Canadian provincial jurisdictions, the number of member trustees and their means of appointment vary and range from sole labour trusteeship to joint trusteeship, with an equal number of employer and employee seats (found in many public sector pension plans), to boards with only one labour representative (Weststar and Verma, 2007). In the province of 
Quebec, member representation in the form of an active and retired plan constituent is legislated. Similar trends exist in other countries. In the UK, a third of pension trustees have to be elected members of the plan, and private sector Taft-Hartley plans in the US must have equal numbers of employer- and union-selected trustees. Public occupational pension plans traditionally have more politically nominated appointments to boards; therefore, this Canadian case study shares resonance with the US and the UK, where fund governance is organised around the conventions of traditional Anglo-Saxon trust model and fiduciary responsibilities (Clark, 2007: 6).

\section{THE POLITICAL NOMINATION APPROACH}

We found an element of political nomination in all cases of labour trustees' recruitment and selection. Generally, labour trustees are recruited by the union. The union executive approaches specific individuals or makes general calls to their internal staff/executive or the rank-and-file membership. Following this 'nomination' potential labour trustees might run for election, be appointed straightaway by the union or be recommended to the employer/government sponsor for appointment. As such, individual union members come to the attention of their union executive through self-selection, union activism/involvement in pension matters or general union activism/involvement. In rare cases, the union may choose to appoint external representatives who tend to be from the financial or business community, or have some particular expertise in pension matters (i.e., Teachers' Pension Plan, Canada Post Pension Plan).

One strength of the political nomination approach is its compatibility with the process used to fill other union jobs. Through their union activities, trustees have gained abilities in leadership, consensus building, public speaking and critical analysis that facilitate their effectiveness in representing their constituents on the pension board. These are the key characteristics of the 'lay trustee' that is so central to principles of prudence (Kakabadse and Kakabadse, 2005). Many labour trustees also cite the importance of a strong 'union world view' or labour perspective to make their boardroom labour voice distinct. Recruiting and selecting candidates based on past union involvement and activism helps in this regard.

However, there are several weaknesses in this approach. The competency and legitimacy of labour trustees can be, and often is, questioned by important others in the pension industry. When regarded as the layperson, labour trustees may be seen by pension staff, industry fund managers and other board members as less expert (Ambachtsheer et al., 2008).

A second weakness is that a political nomination approach operates within existing power structures. In our labour trustee survey, only 3 per cent self-selected (i.e. they were not approached by the union). Unions are political actors; recruitment and selection models that recreate existing institutional norms and power dynamics are problematic. Speaking of similar Anglo-Saxon contexts, Kakabadse and Kakabadse (2005) and Kang et al. (2007) claim that a board functions better where there are a variety of perspectives and experiences; however, boards also have to consider the functional areas of benefits, administration, governance and investment issues in their decision making. So, although direct evidence is not available, we speculate that the nomination approach could exclude people who could be very effective in the trustee role. Similarly, it is likely that many nominated individuals who might be effective as union leaders may prove to be ineffective in the pension trustee role.

A final weakness is the cycle of a democratic election process where job incumbents must stand for re-election at regular intervals. In the political context of a union, it is important to maintain these democratic principles because the union is the voice of the membership and all 
major decisions are ratified at the grassroots level. In the context of pension trusteeship, where the learning curve is steep and the oversight requires a long-term perspective, short board tenure is a disadvantage.

\section{THE HRM APPROACH}

Open recruitment and selection based on valid criteria are integral to HRM models, alongside training and development, performance management and compensation (Storey, 2007). While there is a debate about the different models of HRM, all stress the systematic process of recruitment and selection to ensure strategic or cultural fit (Legge, 1995; Boxall and Purcell, 2011). In this case, it means ensuring fit with pension board strategy, culture and norms as well as the collective constituency of the pension board (Guest, 1987).

In HRM models (Figure 1), the recruitment and selection process normally involves writing a job advertisement based on the job analysis and job description of the vacant position, posting this widely to attract a large pool of applicants, and then using validated tests and interviews to identify the best candidate (CIPD, 2009). This HRM model emerges from the accumulation of research evidence and practical knowledge over several decades (see Cantano et al., 2010 and Taylor, 2010). A formal job analysis ensures a clear understanding of the knowledge, skills and abilities (KSAs) required in the job. This is communicated to the applicants through an accurate job description that also acts to align the role

Figure 1 HRM model of recruitment CIPD (2009) recruitment an overview (http://www.cipd.com)

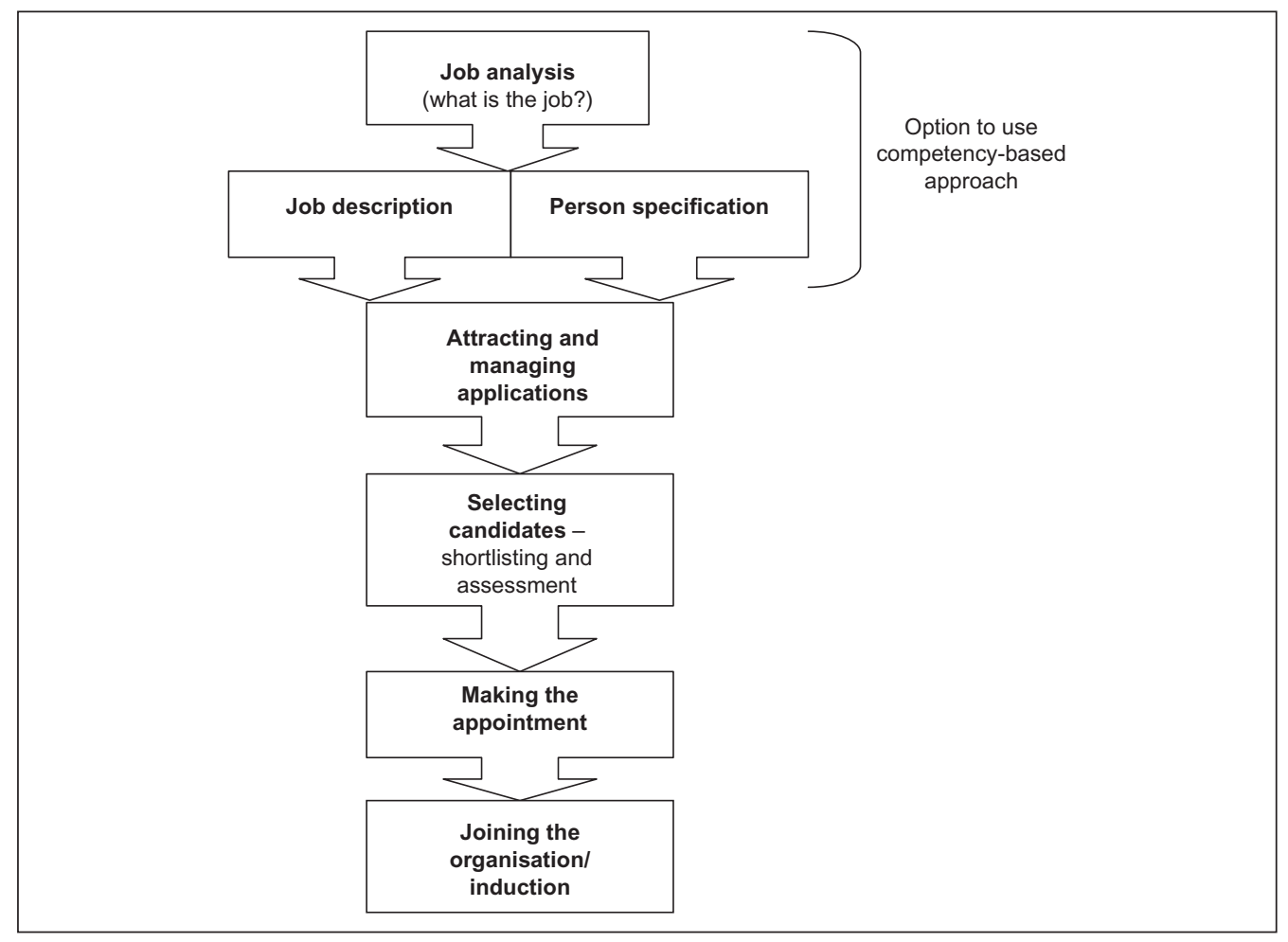


with other jobs within the organisation. Posting the job description in appropriate places ensures that all persons qualified for the job have the opportunity to consider applying. The larger the qualified applicant pool, the greater the likelihood of recruiting an excellent employee. Selection using validated tests and interviews also enhances the likelihood that the chosen candidate would perform well on the job.

This HRM approach is not practised in the selection of labour trustees, so it is important to note its weaknesses for that context. One weakness lies in the emphasis on functional and technical competence over any political or organising skills. A formal job analysis of the pension trustee job could yield a job description that is devoid of the organisational needs of a union to develop its future leaders. Such a job description and the recruitment and selection that follows could be 'technically' efficient in finding a suitable candidate, but it could be suboptimal for the union in its own long-term planning for leadership succession.

A second weakness is that a detailed job analysis would be onerous for each pension board, particularly given that most trustees are already pressured by time and are not compensated well by financial industry standards (Myners, 2001; Ambachtsheer et al., 2008). To further complicate matters, it could be argued that the skills or competencies required for labour trustees differ. For example, relevant past experience for labour trustees would include trade union experience as well as work or life experiences that do not directly relate to pension issues. Similarly, competencies based on activist or alternative investment perspectives (i.e. investing in local communities or unionised employers, using proxy voting to punish poor labour practices or divesting in socially undesirable industries) might not be expected, required or desired for all pension trustees. In practice, then, unions would conduct their own job analysis of the pension trustee role and arrive at different qualifications for trustees than the governments' or employers' qualifications. According to Quarter et al. (2008: 7), this differentiation in roles is critical because of the persistent coercion or undermining of 'lay' trustees by the technocracy (such as fund managers) as the industry attempts to retain hegemony over investment practice and education. For instance, one Canadian fund manager commented:

"While many plans are managed professionally, their boards are sometimes stocked with persons whose principal merit is that they are members, who have been elected by their fellow employees. While this is laudably democratic, it does not always produce the quality of direction and oversight necessary in today's bewildering world" (Canadian Parliament, 1998: 6).

Labour trustees argue differently:

"We can learn the financial stuff - what labor trustees need to have is the strong union perspective/world view... There is no real sense of experts on pension funds - even people with a background in the financial stuff (i.e. accounting etc.) will be lacking other skills essential to running a business" (T10).

An overemphasis on certain skills or competencies such as financial acumen in trusteeship may mean that other crucial aspects such as governance or the benefits aspect of trusteeship are not fully developed. In candidate selection, it may be that the decision becomes one of competition between the suitability of the candidate in relation to industry and union perspectives of professionalism than comparing them to what is actually required in the role. 


\section{DISCUSSION: AN INTEGRATED APPROACH FOR LABOUR TRUSTEES}

As noted above, the political nomination and HRM approaches have unique strengths and weaknesses in the context of labour trustee recruitment and selection. As it is unlikely that all unions would completely forgo the political nomination method in favour of a full-blown HRM approach, we argue that a blended approach could add great value to the process. Already, unions such as the Ontario Public Sector Employees' Union (OPSEU) have instituted a more detailed HRM approach to their appointment process for the OPTrust and OMERS pension boards. For example, the 2011 OPSEU Policy Pensions Manual states:

- advertisement and job description circulated as widely as possible including the OPSEU website;

- membership responses submitted to the Membership Benefits Unit; short list of candidates is prepared by the Pension Liaison Committee;

- short-listed candidates are interviewed by a three-person panel;

- panel recommendations are forwarded to the OPSEU Executive; Committee and Executive Board for review and approval; and

- Executive Board appoints trustees based on assessment and recommendations.

\section{Job analysis}

A challenge with the political nomination approach is the perception that labour representatives are union lackeys or appointed for political reasons. Even a labour trustee comments:

"I feel that largely the union wants to pick rank and filers who will vote the way that they (the union) want and are not expecting much additional value added beyond that" (T9).

Additionally, our data indicate that many labour trustees receive limited guidelines from their unions as to their role and have unclear expectations about their purpose on the board. The question of 'what is the job of a labour trustee' may differ for different unions and different plans, but this can be accounted for in an individualised job analysis that assesses the required tasks and the KSAs required to perform those tasks. This job analysis should also include the tasks and skills required to fulfil any union or labour mandate. The resulting job description would differ depending on individual trade union perspectives towards pensions, the structural characteristics of the board and plan, and board composition. For example, the skills and experience needed for a labour trustee might be different if they are the only labour representative at the table, if they are operating in a joint trusteeship model, if they are one union voice among many other unions or one union voice among multiple employers.

\section{Job description}

The job description and job advertisement explicitly state the expectations of the role as they stem from the job analysis. This acts as a signal to prospective applicants and serves as a performance-guiding framework; any particular characteristics that are valued through the political nomination model could be codified here. For example, a fundamental requirement for labour trustees is that they must be capable of recognising union policy and able to reflect on this from the perspective of all pension plan members in order to avoid a conflict of interest. OPSEU's (2011) job advertisement explicitly states that its labour trustees need an understanding of the union's beliefs and policies as well as the ability to 'articulate where workers sit in relation to the management and investment of capital'. Applicants also must be 
able to formulate a pension position from their reading of documentation and research, defend that position to high-status others, prepare position papers based on 'Union foundations' and know time commitments required.

A statement from a labour trustee and union official confirms many of these responsibilities and illustrates that social and technical competencies as well as structural features of the job (i.e. time commitments) could be identified and formalised in a written job description:

"the role requires a very active voice, it is time consuming, but you do not spend a lot of time negotiating as you delegate; but you have to know what to delegate and you have to be careful about monitoring the delegation and you have to be very careful about being socially responsible and ethical investments; and every so often you really have to bring in a manager, when things start going off the rails and stuff; it's a very active role, it's pretty tiring time-wise and energy-wise" (T27).

Such a job description would more accurately portray the demands of the job so that potential applicants are prepared for the role and its growing time commitments, and recognise its challenges. Also, the job must have a clear and appropriate compensatory arrangement in order to attract and retain the best candidates. As noted by one trustee,

"I think it is very important that trustees are given time off with pay to travel, and prepare for the meetings. It should not cost an employee anything to sit as a trustee" (Interviewee T8).

Most compensatory arrangements for labour trustees are inadequate because trustees are only reimbursed for the time spent at meetings. Also, there is inconsistency in how trustees are reimbursed, with some trustees reporting no compensation at all. It is recommended that the sponsors of pension plans seriously consider the different financial and temporal demands on their trustees and compensate these demands equitably across all trustee types (Ambachtsheer, 2007). Although equitable compensation systems can exist within a political nomination approach to recruitment and selection, a formal process that legitimises successful union candidates would help to make the case for increased compensation for their contributions.

\section{Identifying entry qualifications}

Because of the debate over the KSAs and/or competencies required for pension trustees and the centrality of these to the selection and evaluation process of HRM, we expand our discussion at this point.

Pension fund regulators in Canada do not stipulate the skills required of a pension trustee. As one senior pension administrator noted, a trustee needs to have 'the skill to go out and get knowledge and expertise if required', and he or she has to have enough knowledge to assess and monitor that expert knowledge. Within this context, there is a general recognition that board members need a wide range of skills. These include specific expertise in law, finance and management as well as broader capability with respect to problem solving, facilitating decision making, the maintenance of effective working relationships, communicating with the constituency and leadership bodies, teamworking, and a strong commitment to the role.

In the Ontario Teachers' Pension Plan, there is a clear preference for specific professional skills as labour seats are outsourced to professional trustees: 'Since 1990, the OTF and the Ontario government have successfully attracted board members with the appropriate qualifications in investments, finance, accounting, law, actuarial science, business management and technology to properly oversee management's decisions and actions' (http://www.otpp. com). The implication of this preference is immediately apparent in reviewing the biographies; 
only one of the nine board members has direct experience as a union member and one other is an economist who has consulted for trade unions.

In a blended political nomination and HRM approach, the entry requirements would reflect a balance between the mix of experiences gained through specific training in, or exposure to, pension governance issues and more general skills typically acquired through union activity. It is not surprising that previous involvement in union activities plays a larger part in who gets nominated than expertise in pension matters. One labour trustee felt that if you are a union activist, "that puts you in the pool so to speak" (T11). Another told us that he was "concerned about [formal] evaluation and selection procedures because of the broad knowledge needed [in trusteeship]" (T10). He explained that he did not know anything about pensions when he came to the role, but he had other skills and knowledge (such as leadership and union connections) that have made him a good trustee. If the selection criteria are too rigidly tied to domain-specific skills, these broader oversight skills could be missed or discounted.

We consider in principle that a competency approach permits unions to include labour values and attitudes as well as specific functional skill sets in trustee selection. Continuous learning and recognition of the integrity of the governance process would also fit here. But we recognise that identifying a meaningful range of competencies (Markus et al., 2005) may be beyond the resources or inclination of some trade unions.

Depending on the competencies or skills identified as required qualifications, we can begin to see a continuum of potential labour trustee applicants. On the left would be a political nomination approach that would tend to privilege previous union experience. On the right would be a 'professional' skills approach that would privilege those with pension or financial experience. Two blended options exist. First, unions could employ an HRM approach that focuses on pension aptitude but is applied within the ranks of union membership. This approach can sidestep the politics of the nomination model to some degree, but the specific requirement of pension aptitude likely narrows the pool of potential applicants to union staff or executive members who have served on pensions and benefits committees. Rank-and-file members with different experience would be discounted or self-select out of the pool. In practice, what happens is:

"Labour trustees are normally recruited (by the union) and often include union staff members because they have more time to devote to the issues, more expertise generally in pensions and/or union matters, more consistency of the union message" (Interviewee T9).

Although grounding in a union perspective is a benefit for labour trustees, a pool of individuals already appointed or elected to official union roles may not provide ideal levels of diversity. Therefore, we would recommend a second HRM approach that highlights the need for some pension aptitude in conjunction with grounding in the union world view and the commitment to learn. This latter approach is the model employed by OPSEU, who explicitly state a preference for plan members over union staff (OPSEU, 2011: 6). This preference also helps to reduce the distance between the membership and the labour representative and strengthens the pluralistic assumption upon which representative democracy is based.

\section{Attracting qualified applicants}

In the HRM approach, it is desirable to recruit a large applicant pool to widen selection choice. However, as is the case for most senior executive roles, the numbers of candidates for each pension trustee position are generally small. For labour trustees, the ultimate constraint is typically the requirement to be both a union and pension scheme member. Given the job 
complexity, there are a limited number of rank-and-file members who would meet the criteria. Therefore, it is somewhat unavoidable and perhaps desirable to employ political nomination techniques to identify and encourage potential applicants. However, the political nature of appointments needs to be acknowledged because it would be unlikely that the president/executive would support the candidature of someone with whom they fundamentally disagree. Using clear HRM selection techniques to assess and ultimately select the successful candidate can help mitigate some of the potential bias of political nomination systems.

\section{Selection techniques}

The political nomination method for unions (either appointment or election) is useful because it employs systems already in place and does not add significant administrative burden or costs, particularly when pension governance is not a priority. HRM selection approaches should aim to be as effective as possible while balancing simplicity, time and cost (see Schwind et al., 2007); however, even the simplest techniques such as application letters, written tests or interviews will require additional bureaucracy for the union. Therefore, the priority for a blended approach should be to employ a transparent and fair process that values a range of skills and past experiences without discouraging applicants because of overly onerous or intimidating selection processes or giving the impression of jumping through hoops.

Our data suggest that labour trustees face high temporal demands, a steep learning curve, considerable reading material, covert and overt disinclination of other board members to answer questions, and the general feeling of being on the outside of board proceedings. These findings suggest that the applicants could benefit from a realistic job preview such as an informational meeting with current or outgoing trustees. A type of 'trustee-in-training' system could increase the pool of qualified applicants and permit interested individuals to attend pension training and engage in trustee discussions before they even apply for the job. This would form a pool of previously self-identified 'trainees' for recruitment and selection and also serve an important general education function. To help fulfil the political or representational mandate, this could also be a forum for discussions and guidance about labour's specific role in pension trusteeship.

\section{Induction into the job}

In a political nomination model, there is no explicit provision for job orientation or socialisation. Labour trustees face a steep learning curve and the potential for exclusion at the board table. An HRM approach that encouraged unions to provide ongoing training and access to wider expert and labour trustee networks could better prepare trustees for the upward battle of gaining legitimacy and equip them with the necessary arguments for a stakeholder perspective of pension governance (Carmichael et al., 2003). Existing examples of such support are the trustee education initiatives of the Fédération des travailleurs et travailleuses du Québec (FTQ) and the Shareholder Association for Research and Education. According to a labour trustee and pension specialist, the FTQ plays a crucial role in supporting lay trustees:

"We do have pressure from others in Canada that [pension trustees] shouldn't be union members they should be specialists, because the union members don't have the knowledge or the time to do the job right. And we at FTQ are saying it is possible, we have been doing it for many years... We actually think our trustees are better than employer nominated trustees because they choose to be there" (T24). 
An HRM approach to job incumbency based on job performance and continuous learning also reflects the need to invest in the development of labour trustees and not force trustees from their role if only to comply with democratic principles of unionism that perhaps do not fit this unique role.

\section{OVERVIEW OF A BLENDED MODEL}

Based on the above discussions, we have attempted to dichotomise particular recruitment and selection behaviours into an HRM and political nomination approach (see Table 1). Our argument is that unions would do well to consider recruitment and selection from both approaches based on their own ideologies and realities for labour involvement in pension governance. In sum, the HRM approach could bring more transparency and accountability to the recruitment and selection process. This fits with the ideals of pension governance. An HRM approach does not eliminate all political elements of the recruitment and selection process. Unions have to design their processes to specifically acknowledge that selection can be a 'political exercise that involves different levels of influence and power between power networks of various collaborations, cliques and coalitions' and which act to favour candidates who will help advance the vested interests of these groups (Bozionelos, 2005: 1607). In this way, the HRM model adds legitimacy to labour trustees as they engage in a more competitive process that involves considerations of relevant skills/competencies.

The importance of broad-based experiences rooted in the lives of working people, activism and trade union activities are often discounted in formal credential-based systems (Livingstone and Sawchuk, 2004). The political nomination approach permits these traditional values to be considered and recognises the power dynamics at work in the pension board context. Relationships between the executive members are more influential in the decision-making process than notions of comparative expertise. As a former trade union policy maker and pension expert notes:

"Trustees need to recognise that a lot of the key decisions you end up making regardless of whether you're in a so-called expert environment or a representative environment include making key value judgments [and] are not frankly matters of expertise. As you get to the point of a decision-making process on boards personal interactions becomes incredibly important to the decision making process and there is no expert financial aspect to these things" (T22).

The executive nature of decision making on pension boards is a core activity and skill, but this decision making has a behavioural, political dimension. This is linked to the power and status of the individuals involved and the organisational context in which it operates. Political behaviour is an important feature of trade union activities that influences organisational processes such as recruitment (Treadway et al., 2005). Political savvy gained from years of union activism cannot be discounted. As such, the intention is for trade unions to first analyse the trustee role from an HRM perspective and then move to incorporate political aspects that are fundamental to them as an organisation.

\section{CONCLUSION}

Our analysis suggests that an effective recruitment process for labour trustees should acknowledge the political, regulatory and organisational contexts in order to attract and retain talented individuals. It also needs to consider the emphasis that different trade unions place on 


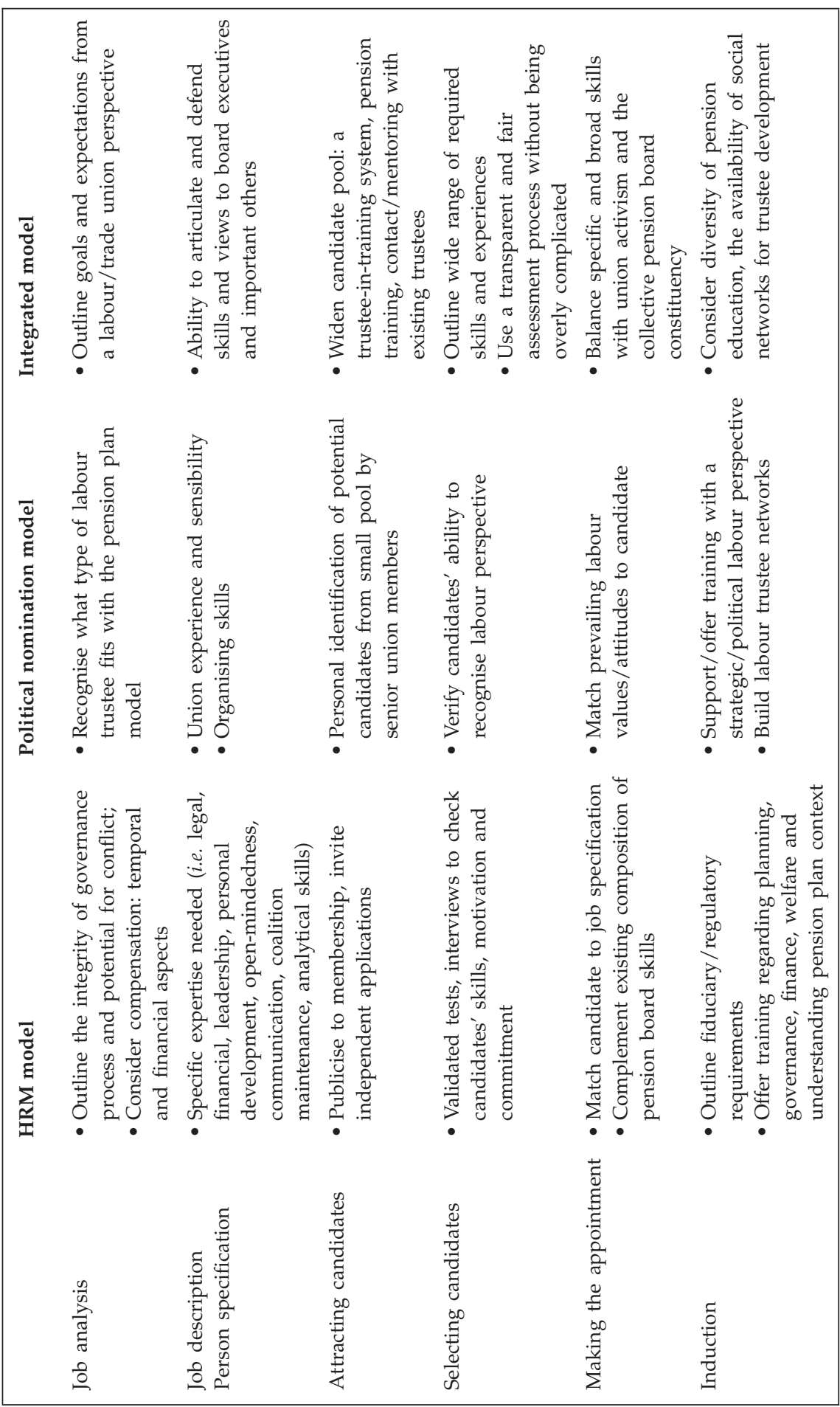

HUMAN RESOURCE MANAGEMENT JOURNAL, VOL •• NO ••, 2012 
pension governance and supporting labour trustees in performing their fiduciary duties. In this regard, neither the professional HRM approach nor the political nomination approach as it is currently practised is likely to yield the best outcomes for unions and their members. A different approach that integrates strengths of both approaches is more likely to help unions place effective trustees on pension boards. An integrated model of recruitment and selection would also need to acknowledge the dynamics of differing political imperatives of both private and public institutions, which can impact on the process by which labour trustees are selected/appointed/elected (Calvert, 2005). The model could also be extended to employer representatives. This would help address how some employer trustees are picked because of their occupational position in the sponsoring company and not for their skills.

Our analysis suggests that effective labour trustees need to be able to respond to the concerns of the labour community while simultaneously maintaining the fiduciary rigour required by law to protect the plan and its constituents. At the heart of these assertions is the need for labour bodies to be explicit about their strategic goals in pension governance. Without this focus on long-term goals, trade unions would be unable to articulate the role of the labour trustee (i.e. conduct job analysis), and unions would find it difficult to develop their own talent in this area. Unless better recruitment and selection processes are put in place, effective labour voice in pension governance will remain elusive.

The similarity of Anglo-Saxon pension trust frameworks and fiduciary responsibilities in North America, the UK and Australia (Hess, 2005; Clark, 2007; Kang et al., 2007) indicates that the integrated model has relevance outside of the Canadian context. In recognising the political context in which nomination occurs in public and private institutions and in strengthening the recruitment and selection of appointed representatives in line with an HRM approach, it can help improve the legitimacy of candidates who represent the membership as well as improve governance.

\section{Note}

1. In 2011, Towers Watson, a consulting firm, estimated US pension assets at $\$ 16.08$ trillion, in the UK at \$2.394 trillion, and in Canada and Australia at \$1.3 trillion each (Towers

Watson, 2012).

\section{REFERENCES}

Ambachtsheer, K. (2007). The Three Grades of Pension Fund Governance Quality: Bad, Better, and Best. Working Paper, July, Rotman Management School, University of Toronto.

Ambachtsheer, K., Capelle, R. and Lum, H. (2008). 'The pension governance deficit: still with us'. Rotman International Journal of Pension Management, 1: 1, 1-14.

Boxall, P. and Purcell, J. (2011). Strategy and Human Resource Management, Basingstoke: Palgrave Macmillan.

Bozionelos, N. (2005). 'When the inferior candidate is offered the job: the selection interview as a political and power game'. Human Relations, 58: 12, 1605-1631.

Calvert, J. (2005). 'Pensions and public-private partnerships: a cautionary note for union trustees'. Just Labour, 5: Winter, 1-13.

Canadian Parliament, (1998). “The Canadian Pension Plan Investment Board: Getting It Right". Report of the Standing Senate Committee on Banking, Trade and Commerce, http://www.parl. gc.ca/Content/SEN/Committee/361/bank/rep/rep11mar98-e.htm, accessed 26 November 2012.

Cantano, V.M., Wiesner, W.H., Hackett, R.D. and Methot, L.L. (2010). Recruitment and Selection in Canada, Toronto: Nelson Education.

Carmichael, I., Thompson, S. and Quarter, J. (2003). 'Transformative education for pension fund trustees'. Canadian Journal for Studies in Adult Education, 17: 1, 1-18. 
Carter, D.A., Simkins, B.J. and Simpson, W.G. (2003). 'Corporate governance, board diversity and firm value'. The Financial Review, 38: 1, 33-53.

CIPD (2009). Recruitment: An Overview, http://www.cipd.co.uk, accessed 8 August 2011.

Clark, G.L. (2007). 'Expertise and representation in financial institutions: UK legislation on pension fund governance and US regulation of the mutual fund industry'. 21st Century Society, 2: 1, $1-23$.

Clark, G.L., Caerlewy-Smith, E. and Marshall, J. (2006). 'Pension fund trustee competence: decision making in problems relevant to investment practice'. Journal of Pension Economics and Finance, 5: 1, 91-110.

Daily, C.M., Dan, R., Dalton, D.R. and Cannella, A.A. (2003). 'Corporate governance: decades of dialogue and data'. Academy of Management Review, 28: 3, 371-382.

Greene, J.C., Caracelli, V.J. and Graham, W.F. (1989). 'Toward a conceptual framework for mixed method evaluation designs'. Educational Evaluation and Policy Analysis, 11: 3, 255-274.

Gribben, C. and Olsen, L. (2002). Will UK Pension Funds Become More Responsible? A Survey of Member Nominated Trustees, London: Just Pensions and UK Social Investment Forum.

Guest, D. (1987). 'Human resource management and industrial relations'. Journal of Management Studies, 24: 5, 503-521.

Hess, D. (2005). 'Protecting and politicizing public fund assets: empirical evidence on the effects of governance structures and practices'. University of California Davis Law Review, 39: 1, 187-227.

Huse, M. (2005). 'Accountability and creating accountability: a framework for exploring behavioural perspectives on boards and governance'. British Journal of Management, 16: S1, 65-79.

Kakabadse, N.K. and Kakabadse, A. (2005). 'Prudence vs professionalism; exploratory examination of pension trustee capability'. Personnel Review, 34: 5, 567-587.

Kakabadse, N.K., Kakabadse, A. and Kouzmin, A. (2003). 'Pension fund trustees: role and contribution'. European Management Journal, 21: 3, 376-386.

Kang, H., Cheng, M. and Gray, S. (2007). 'Corporate governance and board composition: diversity and independence of Australian boards'. Corporate Governance: An International Review, 15: 2, 194-207.

Leblanc, R.W. (2004). 'What's wrong with corporate governance: a note'. Corporate Governance: An International Review, 12: 4, 436-441.

Legge, K. (1995). Human Resource Management, Basingstoke: Macmillan.

Livingstone, D.W. and Sawchuk, P.H. (2004). Hidden Knowledge: Organized Labor in the Information Age, Lanham, MD: Rowman \& Littlefield.

Markus, L.H., Cooper-Thomas, H.D. and Allpress, K.N. (2005). 'Confounded by competencies? An evaluation of the evolution and use of competency models'. New Zealand Journal of Psychology, 34: $2,117-126$.

Myners, P. (2001). Institutional Investment in the United Kingdom: A Review, http://www.hmtreasury.gov.uk/media/2F9/02/31.pdf, accessed 4 October 2007.

OPSEU (2011). OPSEU Policy Manual Section 21 - Pensions, http://www.opseu.org/benefit/ 21\%20-\%20Pensions.pdf, accessed 10 June 2011.

Pye, A. and Pettigrew, A. (2005). 'Studying board context, process and dynamics: some challenges for the future'. British Journal of Management, 16: 1, 27-38.

Quarter, J., Carmichael, I. and Ryan, S. (2008). Pensions at Work: Social Responsible Investment of Union-Based Pension Funds, Toronto: University of Toronto Press.

Rafferty, M., Ham, R. and Bryan, D. (2008). Governance and performance in superannuation fund management - an issues and research design paper prepared for the Australian Institute of Superannuation Trustees.

Rizzo, J.R., House, R.J. and Lirtzman, S.I. (1970). 'Role conflict and ambiguity in complex organizations'. Administrative Science Quarterly, 15: 2, 150-163.

Sayce, S. (2012). 'Being a female pension trustee'. Equality, Diversity and Inclusion: an International Journal, 31: 3, 298-314.

Sayce, S. and Gold, M. (2011). 'Revisiting industrial democracy and pension trusteeship: the case of Canada'. Economy and Industrial Democracy, 32: 3, 477-498. 
Sayce, S. and Ozbilgin, M. (2013). 'Pension trusteeship and diversity in the UK: a new boardroom recipe for change or continuity?'. Economic and Industrial Democracy Journal, forthcoming, doi: $10.1177 / 0143831$ X12462489.

Schwind, H.F., Das, H. and Wagar, T.H. (2007). Canadian Human Resource Management, New York: McGraw-Hill Ryerson.

Storey, J. (2007). Human Resource Management, A Critical Text, London: Thomson Learning.

Tashakkori, A. and Teddlie, C. (eds) (2010). Mixed Methods in Social \& Behavioral Research, 2nd edn, Thousand Oaks, CA: Sage Publications.

Taylor, S. (2010). Resourcing and Talent Management, London: Chartered Institute of Personnel Development.

Treadway, D.C., Hochwarter, W.A., Kacmar, C.J. and Ferris, G.R. (2005). ‘Political will, political skill and political behaviour'. Journal of Organisational Behaviour, 26: 3, 229-245.

Tyson, L.D. (2003). Report on the Recruitment and Development of Non-Executive Directors, London: Department of Trade and Industry, June.

Van Der Walt, N., Ingley, C., Shergill, G.S. and Townsend, A. (2006). 'Board configuration: are diverse boards better boards?'. Corporate Governance, 6: 2, 129-147.

Verma, A. and Weststar, J. (2011). 'Token presence or substantive participation? A study of labor trustees on pension boards'. Journal of Labor Research, 32: 1, 39-60.

Watson, T. (2012). Global Pension Assets Study 2012, http:/ /www.towerswatson.com, accessed 20 May 2012.

Weststar, J. and Verma, A. (2007). 'What makes for effective labor representation on pension boards?'. Labour Studies Journal, 32: 4, 382-410.

Weststar, J. and Verma, A. (2008). 'Just having it is not enough: labour's voice on pension boards', in J. Quarter, I. Carmichael and S. Ryan (eds), Pensions at Work: Socially Responsible Investment of Union-Based Pension Funds, Toronto, ON: University of Toronto Press.

Woods, C. and Urwin, R. (2010). 'Putting sustainable investing into practice: a governance framework for pension funds'. Journal of Business Ethics, 92: 1, 1-19. 